\title{
Official response to the Syrian refugee crisis in Lebanon, the disastrous policy of no-policy Dr. Karim El Mufti
}

\begin{abstract}
This article examines the impact of the Lebanese State's policy of no-policy regarding Syrian refugees in Lebanon.
\end{abstract}

Keywords: Syrian Refugees, Official response, Lebanese State

To cite this paper: Dr. Karim El Mufti, "Official response to the Syrian refugee crisis in Lebanon, the disastrous policy of no-policy ", Civil Society Knowledge Center, Lebanon Support, January, 2014 . DOI: 10.28943/CSKC.002.20001.

[ONLINE]:

https://civilsociety-centre.org/paper/official-response-syrian-refugee-crisis-lebanon-disastrous-policy-nopolicy

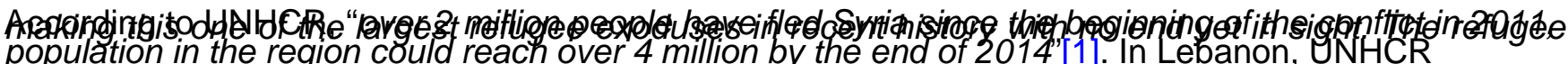
recorded 858.641 refugees by 31st December 2013[2], and some media reports skyrocket the number through the roof claiming that more than a million refugees are already living in the country. This short paper offers an insight on how the Lebanese authorities reacted to this humanitarian crisis, and points out the (absence of) policy from the relevant decision makers.
\end{abstract}

Designing a policy in normal circumstances is an extremely complex machinery that involves gathering large amount of relevant data around a specific issue before exploring appropriate solutions to solve and ease problems facing particular groups within a society. This very technical process must always be accompanied with strong political will for it to be successfully implemented before it is evaluated and eventually corrected, if needed. So in emergency and disaster-related situations, the context becomes even harsher and requires a higher level of organization and coordination from the relevant authorities. Lebanon, as one can imagine, lacks the requirements for shaping consistent and comprehensive policies in accord with the needs of public interest, adding to the factors that are in fact worsening the refugee crisis in the country.

This situation created a sort of no-policy context coming from the Lebanese authorities in regards to the Syrian influx of refugees who are protected under international refugee law and the international law of armed conflict is tangible on many levels, from the lack of political will, to a sense of confusion and the implementation of contradictory measures.

Because the main focus of the Lebanese government, as the Syrian refugee crisis erupted, was securing international funds to help with humanitarian assistance, whether through multi-donors trust funds or other mechanisms[3], the officials did not develop any form of planning on the actual status 
and living conditions of the refugees coming from Syria. One of the first dilemmas the Lebanese government and security services had to overcome was whether to consider the option of setting up refugee camps for the growing number of refugees arriving from Syria. Haunted by the Palestinian experience in Lebanon, by the time the Lebanese authorities and security services discarded the very idea of organizing the relief work through refugee camps, the negative decision no longer mattered as 'unofficial' camps were flourishing in a disorganized manner in the North and the Bekaa, while international aid organizations were struggling with a growing catastrophic humanitarian disaster[4].

As a consequence, the de facto rule imposed itself over the no-camp policy as no measures were being studied by the relevant authorities to regulate the living conditions in the unofficial camps where local communities have seized the prerogative of "law and order" in the absence of official services[5]. On a local level, as far as 25 municipalities in Lebanon started imposing curfews for Syrians and foreigners in general, disregarding the fact that many foreigners, including Syrians, own houses and apartments in Lebanon since before the war in Syria. From a legal point of view, these curfews are deemed "unconstitutional and illegal" according to lawyer and human rights activists Nizar Saghiye[6].

Moreover, these refugees came to be accused of competing with the Lebanese on the local labor market in order to survive[7], making the absence of a comprehensive humanitarian policy on a national level an additional aggravation factor to the worsening of the economic situation in the country. This drew reactions from Lebanese economical bodies and eventually political figures pressuring the government to survey and crack down on illegal Syrian businesses[8]. But these allegations of negative impacts of Syrian refugees are often exaggerated and misplaced as stressed by economist Jad Chaaban who uncovered the positive effects of the presence of refugees in local villages: "for the first time you have people spending money in these areas. You have a local economy that has been created"[9].

More dangerously, the political class was divided as to whether to even allow Syrian refugees to stay in Lebanon as their homes were being torn down by the neighboring conflict. Free Patriotic Movement Minister Gebran Bassil was one of the most outspoken political figures to call for the "deportation of Syrian refugees"[10], promoting demographic fears at the expense of Lebanese obligations under International Humanitarian Law, whereas his political opponents backed the idea of supporting and assisting the fleeing Syrians into Lebanon, but without offering any viable policy solutions.

Under such political divide, the General Security, in charge of the asylum seeking mechanism in the country, contributed to the confusion using its discretionary powers as it first started to arbitrarily arrest Syrian refugees disregarding their legal condition[11], a harsh policy that often came with deportation[12]. The latter constitutes an illegal measure in regards to the principle of "non refoulement" that forbids States of expelling persons back to their countries when they can be at risk of being persecuted or fleeing because of war. The situation was reversed thanks to the pressure of watch groups and the International Committee of the Red Cross (ICRC). As stated by the head of the ICRC delegation in Lebanon, "since last May, we have had dialogue with the Lebanese authorities on the principle of non-refoulement. The Lebanese authorities have committed to respecting this principle, whoever the people concerned'[13]. From the perspective of Human Rights Watch Director in Lebanon, Nadim Houry, "Syria welcomed many Lebanese fleeing war back in 2006. Now it's time to return the favor. Lebanon should be offering immediate refuge to Syrians fleeing death or torture in their 
country"[14].

Confusion and the absence of policy related mechanisms in Beirut also hindered the efforts to ease the living conditions of Syrian refugees in Lebanon. For instance, in July 2013, the Swedish company IKEA had offered to provide UNHCR and the Lebanese authorities with prefabricated houses for Syrian refugees to live in, which was initially rejected by the Lebanese government[15]. Finally, Lebanese authorities caved to the idea in December 2013, in the middle of a fierce and deadly winter for refugees, especially children[16]. For Roberta Russo, communication officer for UNHCR, this initiative "provided solutions to so many issues - children can study homework at night, there is privacy and it's easy to set up." Most important, she says, is that it's portable. It's a structure that can be taken with the refugees when they go home. It's quite likely that when these refugees return to Syria, they won't have a house to go back to, so this structure actually better facilitates their return"[17].

As the war in Syria continues and the number of refugees is likely to keep on increasing, the passive approach of Lebanese decision makers remains the rule, instead of using the policy tools at hand. Instead of relying on isolated and ill-resourced institutions to deal with such a large scale crisis (High Relief Committee or Ministry of Social Affairs for instance) or leaving it to local and international relief organizations to handle, the government should mobilize all resources at hand, establish an interministerial committee or a special task force for the coordination of all refugees-related issues (shelter, health, relief, education, legal status, financial aid...), recruit experts to be better informed on all available options, and create specific monitoring cells within public institutions to get better reports and data. Hence, build a better response.

Furthermore, specific parliamentarian task forces should also gather urgently and review the present legislation and, if necessary, legislate on the many legal gaps adding to the present confusion as per the official response by the authorities. This would help the Executive branch of the government understand and enforce the legal status of Syrian refugees entering into the country, thus clarifying the legal framework pertaining to the rights and obligations of those refugees staying temporarily on Lebanese soil. Moreover, these clarifications will help regulate and set limits to the work of administrative authorities (police, General Security, Ministries, Municipalities, etc.) when dealing with the refugees each on its respective level. As such, a comprehensive nationwide policy effort on the Syrian refugee crisis constitutes, now more than ever, a high level priority for Lebanon's decision makers.

(*) Dr. Karim EL MUFTI: University Professor, expert in International Human Rights and Humanitarian Law \& Social Entrepreneur

Photo credits: Getty Images

To cite this article: Karim El Mufti, "Official response to the Syrian refugee crisis in Lebanon: the 
disastrous policy of no-policy", Civil Society Knowledge Center, Lebanon Support, 10 January 2014. [online] civilsociety-centre.org/paper/official-response-syrian-refugee-crisis-lebanon-disastrous-policyno-policy

[1] UNHCR Syria page, cf. http://www.unhcr.org/syriarrp6/

[2] Source: UNHCR, http://data.unhcr.org/syrianrefugees/regional.php

[3] By December 2012, the Lebanese government had obtained "a total of $\$ 179,276,320$ [...] to the Syrian refugees in Lebanon by the various concerned ministries", Cf. "Miqati: Lebanon Can No Longer Support Burden of Syrian Refugees Alone", Naharnet, 3 December 2012, http://www.naharnet.com/stories/en/63145.

[4]World Refugee Day: UN calls Syria 'worst humanitarian disaster' since cold war, Christian Science Monitor, 20 June

2013, http://www.csmonitor.com/USA/Foreign-Policy/2013/0620/World-Refugee-Day-UN-calls-Syriaworst-humanitarian-disaster-since-cold-war

[5] "Lebanese burn down Syrian refugee camp", Al Akhbar, 2 December 2013, http://english.al-akhbar.com/node/17783 
[6] Conference on the Situation of Syrian Refugees in Lebanon, Norwegian Refugee Council, Beirut, 21 June 2013.

[7] One needs to remember that Syrian labor was already very sizeable in Lebanon even before the war in Syria and the refugee crisis.

[8] “Lebanon to survey unlicensed Syrian businesses”, The Daily Star, 25 November 2013, http://www.dailystar.com.lb/Business/Lebanon/2013/Nov-25/238763-lebanon-to-surveyunlicensed-syrian-businesses.ashx

[9]"Syrian refugees burden and benefit for Lebanese economy", Reuters, 17 April 2013, http://www.reuters.com/article/2013/04/17/us-crisis-lebanon-refugeesidUSBRE93G0MW20130417

[10]“Bassil calls for deporting Syrian refugees”, Now Lebanon, 27 September 2013, https://now.mmedia.me/lb/en/lebanonnews/bassil-calls-for-deporting-syrian-refugees

[11] Read Human Rights Watch bulletin: "Lebanon: Stop Detaining Syrian Refugees", 20 May 2011, http://www.hrw.org/node/99112

[12] "Letter to Lebanese Officials Regarding Deportation of Syrians", Human Rights Watch, 4 August 
2012, http://www.hrw.org/news/2012/08/04/letter-lebanese-officials-regarding-deportation-syrians ; "EU urges Lebanon not to send back Syrian refugees", The Daily Star, 4 August 2012, http://dailystar.com.Ib/News/Local-News/2012/Aug-04/183411-eu-urges-lebanon-not-to-sendback-syrian-refugees.ashx\#ixzz2pdJJMCXz

[13] Quoted by Hala Naufal, S"yrian Refugees in Lebanon: The Humanitarian Approach under Political Divisions", Migration Policy Center, MPC Research Report 2012/13, 2012, p.

12, http://www.migrationpolicycentre.eu/docs/MPC\%202012\%2013.pdf

[14]"Stop Detaining Syrian Refugees”, Human Rights Watch 20 May 2011, http://www.hrw.org/node/99112

[15]“Lebanon says no to Ikea Housing for Syrian Refugees”, Times, 16 December 2013, http://world.time.com/2013/12/16/lebanon-says-no-to-ikea-housing-for-syrian-refugees-becauseits-too-nice/

[16]Report: "3-Month-Old Syrian Dies from Cold in Akkar", Naharnet, 13 December 2013, http://www.naharnet.com/stories/en/109770 ; "Child deaths and bitter cold in Syrian refugee camps", Reuters, 16 December 2012, http://www.reuters.com/article/2012/12/16/us-syria-crisis-refugees-idUSBRE8BF03520121216

[17]Quoted in Times, "Lebanon says no to Ikea Housing for Syrian Refugees", op. cit. 
Civil Society

Knowledge

$\because$ Centre 